\title{
Effect of Cement Factory Exhaust on Radiological Contents of Surrounding Soil Samples in Assuit Province, Egypt
}

\author{
Atef El-Taher, ${ }^{1}$ Laith Ahmed Najam, ${ }^{2 *}$ Afrah Hassoon Oraibi ${ }^{3}$ and \\ Matthew Omoniyi Isinkaye ${ }^{4}$
}
${ }^{1}$ Physics Department, Faculty of Science, Al-Azhar University, Assuit 71452, Egypt
${ }^{2}$ Physics Department, College of Science, Mosul University, Mosul, Iraq
${ }^{3}$ Electrical Engineering Department, College of Engineering,
Kufa University, Kufa, Iraq
${ }^{4}$ Radiation, Health and Environmental Physics Group, Physics Department, Ekiti State University, Ado Ekiti, Nigeria

*Corresponding author: Prof.lai2014@gmail.com

Published online: 15 November 2017

To cite this article: El-Taher, A. et al. (2017). Effect of cement factory exhaust on radiological contents of surrounding soil samples in Assuit province, Egypt. J. Phys. Sci., 28(3), 137-150, https://doi.org/10.21315/jps2017.28.3.9

To link to this article: https://doi.org/10.21315/jps2017.28.3.9

\begin{abstract}
In the present work, the natural radioactivity of surrounding soil samples collected from Assuit cement factory (Egypt) have been measured by using NaI(Tl) detector. Gamma analysis for each sample along with the calculated specific activities shows that the average concentrations of Ra-226, Th-232 and $\mathrm{K}-40$ were $31.44 \pm 3.67 \mathrm{~Bq} \mathrm{~kg}^{-1}, 39.77$ $\pm 2.00 \mathrm{~Bq} \mathrm{~kg}{ }^{-1}$ and $113.23 \pm 5.66 \mathrm{~Bq} \mathrm{~kg}^{-1}$ respectively, where only the values of $\mathrm{Ra}-226$ and $K-40$ are lower than the worldwide average, while the average value of radium equivalent activity, absorbed gamma dose rate, external and internal hazard indices, gamma index, alpha index, indoor and outer door effective doses for each sample were $132.02 \mathrm{~Bq} \mathrm{~kg}^{-1}$, $43.27 \mathrm{nGy} \mathrm{h}^{-1}, 0.256,0.346,0.691,0.157,0.212 \mathrm{mSv} \mathrm{y}^{-1}$ and $0.0572 \mathrm{mSv} \mathrm{y}^{-1}$ respectively. All these values were found to be lower than the permissibility limit value.
\end{abstract}

Keywords: Cement exhaust, natural radioactivity, radium equivalent activity, soil, annual effective dose

\section{INTRODUCTION}

Soil is the upper part of the earth's crust and formed as a result of rock deformation by complex physicochemical processes including weathering decomposition, water movement and organic matter addition. Soil consists of minerals, organic matter, water and air. Their percentages vary widely according to soil type, usage, 
and particle size. ${ }^{1}$ Natural radioactivity is widespread in the earth's environment. It exists in soil, plant, water, air, coal and phosphate. The natural radioactivity in soil comes mainly from ${ }^{238} \mathrm{U}$ series, ${ }^{232} \mathrm{Th}$ series and ${ }^{40} \mathrm{~K}$. One of the components of external gamma-ray exposure to which a person is exposed to regularly is the naturally occurring radioactive materials (NORMs) in soil. Natural environmental radioactivity and the associated external exposure due to gamma radiation depend primarily on geological and geographical conditions, and exist at different levels in the soils of each region in the world. The specific levels of terrestrial environmental radiation are related to the geological composition for each lithological separated area, and to the content of uranium, thorium and potassium in the rock from which the soil originated in each area. ${ }^{2}$

High levels of uranium and its decay products in rock and soil and thorium in monazite sands are the main sources of high natural background areas that have been identified in several areas of the world, e.g., Yangjiang in China, Rasmar in Iran, Kerala coast of India, etc. ${ }^{3}$ Therefore, measurements of natural radioactivity in soil are of a great interest for many researchers throughout the world, which led to worldwide national surveys in the last two decades. El-Taher et al. studied the elemental analysis of Toshki soil in south Egypt by instrumental neutron activation analysis, and also the radioactivity in soil samples from Wadi Al-Assuity protective area in Upper Egypt. ${ }^{4,5}$

The authors measured the ${ }^{226} \mathrm{Ra},{ }^{232} \mathrm{Th}$ and ${ }^{40} \mathrm{~K}$ levels in phosphate fertiliser and its environmental implications in Assuit governorate, Upper Egypt. ${ }^{6}$ More specifically, natural environmental radioactivity due to gamma radiation depends primarily on the geological and geographical conditions, and appears at different levels in the soils of each region in the world. ${ }^{3}$

Because there are no existing databases for the natural radioactivity in soil around cement factory, our results are a start to establishing a database for cement factory environment. It is hoped that the data presented here will be useful to those dealing with soil and related fields. The aim of the present work is to assess the activity concentration levels of naturally occurring radionuclides such as ${ }^{226} \mathrm{Ra}$, ${ }^{232} \mathrm{Th}$ and ${ }^{40} \mathrm{~K}$ in some soil samples around cement factory. Additionally, the radiological parameters due to natural radionuclides in soil will also be considered. This database will be used as reference to gauge any input sand trans boundary radioactive release in future. 


\section{EXPERIMENTAL}

\subsection{Sample Collection and Preparation}

A total of 21 soil samples were collected from around Assuit cement factory, Egypt. The samples were ground, homogenised and sieved to about 100 mesh by a crushing machine. The samples were dried at $110^{\circ} \mathrm{C}$ to ensure that moisture is completely removed. Samples weighing $1 \mathrm{~kg}$ each were placed in beaker of $350 \mathrm{~cm}^{3}$ volume. The beakers were sealed completely for over one month to allow radioactive equilibrium to be reached. This is a necessary step to ensure that radon gas is adequately confined within the volume, and that the daughters will also remain in the sample..$^{5-7}$

\subsection{Samples Counting}

Specific activates were performed using gamma ray spectrometer, employing a $\mathrm{NaI}(\mathrm{Tl})$ scintillation detector $3 " \times 3 "$. The assembly is hermetically sealed, and includes a $\mathrm{NaI}(\mathrm{Tl})$ crystal, coupled to PC-MCA Canberra Accuspe. To reduce the gamma ray background, a cylindrical lead shield of $100 \mathrm{~mm}$ in thickness with a fixed bottom and movable cover shielded the detector. The lead shield contained an inner concentric cylinder of copper $(0.3 \mathrm{~mm}$ thick) to absorb X-rays generated in the lead. To determine the background distribution in the environment around the detector, an empty sealed beaker was counted in the same manner and in the same geometry as the samples. The $\gamma$-ray spectrometer energy was calibrated using ${ }^{60} \mathrm{Co}$ and ${ }^{137} \mathrm{Cs}$ point sources. The naturally occurring radionuclides considered in the present analysis of the measured $\gamma$-ray spectra are: ${ }^{212} \mathrm{~Pb}$ (with a main gamma energy at $\sim 239 \mathrm{keV}$ and a gamma yield of $\sim 43.1 \%) ;{ }^{214} \mathrm{~Pb}(\sim 352 \mathrm{keV}, \sim 37.1 \%) ;{ }^{214} \mathrm{Bi}$ ( $\sim 609 \mathrm{keV}, \sim 1120 \mathrm{keV}$ and $\sim 1765 \mathrm{keV}, \sim 46.1 \%, \sim 15 \%$ and $\sim 15.9 \%$ respectively); ${ }^{228} \mathrm{Ac}(\sim 911 \mathrm{keV}, \sim 29 \%) ;{ }^{208} \mathrm{Tl}(\sim 2615 \mathrm{keV}, \sim 35.9 \%)$; and ${ }^{40} \mathrm{~K}(\sim 1461 \mathrm{keV}, \sim 10.7 \%)$. Under the assumption that secular equilibrium was reached between ${ }^{232} \mathrm{Th}$ and ${ }^{238} \mathrm{U}$ and their decay products, the specific activity of ${ }^{232} \mathrm{Th}$ was determined from the average specific activities of ${ }^{212} \mathrm{~Pb},{ }^{208} \mathrm{Tl}$ and ${ }^{228} \mathrm{Ac}$ in the samples, and that of ${ }^{226} \mathrm{Ra}$ was determined from the average concentrations of the ${ }^{214} \mathrm{~Pb}$ and ${ }^{214} \mathrm{Bi}$ decay products. The $\gamma$-ray spectrometer energy was calibrated using ${ }^{60} \mathrm{Co}$ and ${ }^{137} \mathrm{Cs}$ point sources. The measuring time for gamma-ray spectra range was $12 \mathrm{~h}$. In order to determine the background distribution due to naturally occurring radionuclides in the environment around the detector, an empty backer was counted in the same manner as the samples. After measurement and subtraction of the background, the specific activity was calculated by the equation: ${ }^{8}$ 


$$
\mathrm{A}=\mathrm{Net} \operatorname{count} / \varepsilon^{*} \mathrm{I} \gamma^{*} \mathrm{~m} * \mathrm{t}
$$

where:

$\mathrm{A}=$ activity concentrations of the sample in units $\mathrm{Bq} \mathrm{kg} \mathrm{kg}^{-1}$

$\mathcal{E}=$ energy efficiency

$\mathrm{m}=$ mass of sample in unit $\mathrm{kg}$

$\mathrm{t}=$ time measurement $(43200 \mathrm{~s})$

$\mathrm{I} \gamma=$ gamma intensity

\section{RESULTS AND DISCUSSION}

Specific activities of ${ }^{226} \mathrm{Ra},{ }^{232} \mathrm{Th}$ and ${ }^{40} \mathrm{~K}$ in 21 of the surrounding soil samples for cement factory exhaust in Assuit province were shown in Table 1. From Table 1, it is observed that the specific activity of ${ }^{226} \mathrm{Ra}$ ranged from $21.37 \pm$ $3.5 \mathrm{~Bq} \mathrm{~kg}^{-1}$ in Sample 5 to $40.19 \pm 2.27 \mathrm{~Bq} \mathrm{~kg}^{-1}$ in Sample 18 with an average value of $31.44 \pm 3.67 \mathrm{~Bq} \mathrm{~kg}^{-1}$. For ${ }^{232} \mathrm{Th}$, the specific activity ranged from $1.78 \pm$ $0.14 \mathrm{~Bq} \mathrm{~kg}^{-1}$ in Sample 2 to $70.82 \pm 3.55 \mathrm{~Bq} \mathrm{~kg}^{-1}$ in Sample 11 with an average value of $39.77 \pm 2.00 \mathrm{~Bq} \mathrm{~kg}^{-1}$. On the other hand, for ${ }^{40} \mathrm{~K}$ activity, the values ranged from $90.32 \pm 4.52 \mathrm{~Bq} \mathrm{~kg}^{-1}$ in Sample 5 to $130.48 \pm 6.25 \mathrm{~Bq} \mathrm{~kg}^{-1}$ in Sample 7 with an average value of $113.23 \pm 5.66 \mathrm{~Bq} \mathrm{~kg}^{-1}$. For the average value of specific activity of present study, value of ${ }^{226} \mathrm{Ra}$ is lower than the world average of $32 \mathrm{~Bq} \mathrm{~kg}^{-1}$, activity for ${ }^{232} \mathrm{Th}$ is lower than world average value of $45 \mathrm{~Bq} \mathrm{~kg}^{-1}$, and activity of ${ }^{40} \mathrm{~K}$ is also lower than the world average value of $412 \mathrm{~Bq} \mathrm{~kg}^{-1} \cdot{ }^{16}$ Other observation from Table 1 is the specific activity of ${ }^{40} \mathrm{~K}$ is higher than the specific activity of radionuclides such as ${ }^{226} \mathrm{Ra}$ and ${ }^{232} \mathrm{Th}$ for all samples. The specific activities values of ${ }^{226} \mathrm{Ra},{ }^{232} \mathrm{Th}$ and ${ }^{40} \mathrm{~K}$ in the surrounding soil samples for cement factory exhaust are shown in Figure 1.

Table 1: Specific activity concentrations of ${ }^{226} \mathrm{Ra},{ }^{232} \mathrm{Th}$ and ${ }^{40} \mathrm{~K}$ for soil samples surrounding Assuit cement factory.

\begin{tabular}{cccc}
\hline \multirow{2}{*}{$\begin{array}{c}\text { Sample } \\
\text { locations }\end{array}$} & Ra-226 & Th-232 & \multicolumn{1}{c}{ K-40 } \\
\cline { 2 - 4 } & $33.74 \pm 3.71$ & $41.11 \pm 2.07$ & $118.40 \pm 5.92$ \\
2 & $27.26 \pm 3.47$ & $1.78 \pm 0.14$ & $119.93 \pm 6.00$ \\
3 & $31.58 \pm 4.27$ & $38.35 \pm 1.93$ & $121.42 \pm 6.07$ \\
4 & $30.67 \pm 3.63$ & $37.87 \pm 1.90$ & $105.48 \pm 5.27$ \\
5 & $21.37 \pm 3.50$ & $30.84 \pm 1.55$ & $90.32 \pm 4.52$ \\
6 & $33.06 \pm 4.01$ & $40.45 \pm 2.03$ & $123.70 \pm 6.19$ \\
\hline
\end{tabular}


Table 1 (Continued)

\begin{tabular}{cccc}
\hline \multirow{2}{*}{$\begin{array}{c}\text { Sample } \\
\text { locations }\end{array}$} & Ra-226 & Th-232 & K-40 \\
\cline { 2 - 4 } 7 & $30.44 \pm 3.53$ & $30.72 \pm 1.55$ & $130.48 \pm 6.52$ \\
8 & $31.12 \pm 4.39$ & $2.88 \pm 0.19$ & $110.02 \pm 5.50$ \\
9 & $31.30 \pm 4.69$ & $40.11 \pm 2.01$ & $112.45 \pm 5.62$ \\
10 & $28.80 \pm 3.89$ & $2.45 \pm 0.12$ & $106.76 \pm 5.34$ \\
11 & $36.74 \pm 3.80$ & $70.82 \pm 3.55$ & $118.95 \pm 5.95$ \\
12 & $33.07 \pm 3.92$ & $42.89 \pm 2.15$ & $116.46 \pm 5.82$ \\
13 & $31.75 \pm 3.62$ & $42.61 \pm 2.14$ & $122.16 \pm 6.11$ \\
14 & $29.15 \pm 3.93$ & $37.10 \pm 1.86$ & $114.92 \pm 5.75$ \\
15 & $37.18 \pm 4.12$ & $61.45 \pm 3.08$ & $117.55 \pm 5.88$ \\
16 & $27.06 \pm 3.30$ & $36.86 \pm 1.85$ & $100.09 \pm 5.01$ \\
17 & $21.63 \pm 1.40$ & $30.56 \pm 1.54$ & $94.16 \pm 4.71$ \\
18 & $40.19 \pm 2.27$ & $70.31 \pm 3.52$ & $119.47 \pm 5.97$ \\
19 & $36.43 \pm 4.22$ & $37.54 \pm 1.89$ & $111.00 \pm 5.55$ \\
20 & $31.23 \pm 3.41$ & $69.30 \pm 3.47$ & $106.81 \pm 5.34$ \\
21 & $36.45 \pm 4.14$ & $69.32 \pm 3.48$ & $117.37 \pm 5.87$ \\
\hline Average \pm S.D. & $31.44 \pm 3.67$ & $39.77 \pm 2.00$ & $113.23 \pm 5.66$ \\
\hline Worldwide average & 35 & 30 & 400 \\
\hline
\end{tabular}

Ra-226, Th-232 and K-40 concentrations

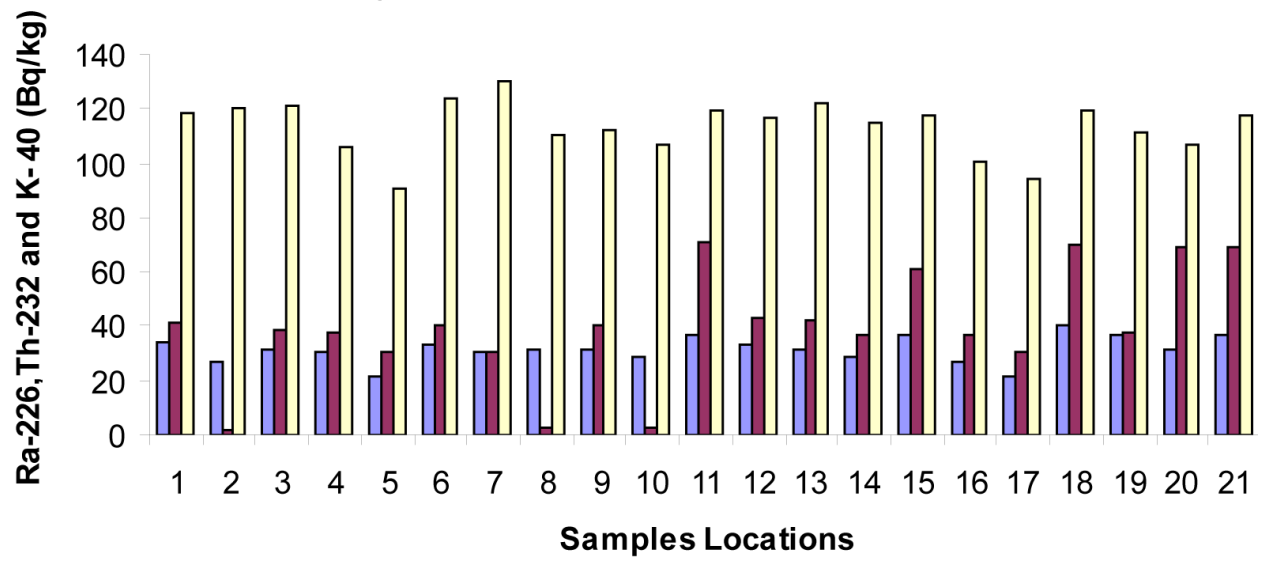

Figure 1: Specific activity concentrations of ${ }^{226} \mathrm{Ra},{ }^{232} \mathrm{Th}$ and ${ }^{40} \mathrm{~K}$ for soil samples surrounding Assuit cement factory. 


\subsection{Radiological Parameters}

\subsubsection{Radium equivalent activity $\left(\mathbf{R} \mathbf{a}_{\mathrm{eq}}\right)$}

The natural radioactivity of cement material is usually determined from the contents of ${ }^{226} \mathrm{Ra},{ }^{232} \mathrm{Th}$ and ${ }^{40} \mathrm{~K}$. Since $98.5 \%$ of the radiological effects ${ }^{238} \mathrm{U}$ series are produced by ${ }^{226} \mathrm{Ra}$ and its daughter products, the contribution from the ${ }^{238} \mathrm{U}$ was replaced with the decay product ${ }^{226} \mathrm{Ra}$. As sand beach minerals, rejected light sands and sea beach soils can be used in industries and building constructions, the $\gamma$-ray radiation hazards due to the specified radionuclides were assessed by three different indices. Radium equivalent activity is an index introduced to represent the specific activities of ${ }^{226} \mathrm{Ra},{ }^{232} \mathrm{Th}$ and ${ }^{40} \mathrm{~K}$ by a single quantity, taking into account the radiation hazards associated with them. The radium equivalent activity can be calculated according the following equation below: ${ }^{9}$

$$
\mathrm{Ra}_{\mathrm{eq}}=A_{\mathrm{Ra}}+1.43 A_{\mathrm{Th}}+0.077 A_{\mathrm{K}}
$$

where $A_{\mathrm{Ra}}, A_{\mathrm{Th}}$ and $A_{\mathrm{K}}$ are the specific activities of ${ }^{226} \mathrm{Ra},{ }^{232} \mathrm{Th}$ and ${ }^{40} \mathrm{~K}$ in $\mathrm{Bq} \mathrm{kg}^{-1}$, respectively. The $\mathrm{Ra}_{\mathrm{eq}}$ is related to the external $\gamma$-dose and internal dose due to radon and its daughters. From Table 2, it can be noticed that the values of $\mathrm{Ra}_{\mathrm{eq}}$ ranged from $38.21 \mathrm{~Bq} \mathrm{~kg}^{-1}$ in Sample 2 to $149.10 \mathrm{~Bq} \mathrm{~kg}^{-1}$ in Sample 18 with an average value of $96.24 \mathrm{~Bq} \mathrm{~kg}^{-1}$. The global limit of $\mathrm{Ra}_{\mathrm{eq}}$ in building materials must be less than $370 \mathrm{~Bq} \mathrm{~kg}^{-1}$ for safe use. ${ }^{9}$

Table 2: $\mathrm{Ra}_{\mathrm{eq}}, \mathrm{D}, \mathrm{H}_{\mathrm{ex}}, \mathrm{H}_{\mathrm{in}}, \mathrm{I}_{\gamma}$ and $\mathrm{I}_{\alpha}$ of soil samples.

\begin{tabular}{ccccccc}
\hline Sample locations & Raeq $\left(\mathrm{Bq} \mathrm{kg}^{-1}\right)$ & Dose rate $\left(\mathrm{nGy} \mathrm{h}^{-1}\right)$ & $\mathrm{Hex}$ & $\mathrm{H}_{\mathrm{in}}$ & $\mathrm{I}_{\gamma \mathrm{r}}$ & $\mathrm{I} \alpha$ \\
\hline 1 & 100.82 & 45.36 & 0.273 & 0.362 & 0.714 & 0.168 \\
2 & 38.21 & 18.67 & 0.105 & 0178 & 0.281 & 0.138 \\
3 & 94.91 & 42.81 & 0.258 & 0.343 & 0.674 & 0.158 \\
4 & 92.21 & 41.44 & 0.250 & 0.333 & 0.652 & 0.153 \\
5 & 71.79 & 32.27 & 0.195 & 0.253 & 0.510 & 0.1068 \\
6 & 99.56 & 44.86 & 0.270 & 0.360 & 0.706 & 0.165 \\
7 & 83.50 & 38.06 & 0.228 & 0.309 & 0.597 & 0.152 \\
8 & 42.94 & 20.71 & 0.118 & 0202 & 0.309 & 0.155 \\
9 & 96.54 & 43.38 & 0.262 & 0.347 & 0.684 & 0.156 \\
10 & 39.77 & 19.24 & 0.109 & 0.187 & 0.287 & 0.144 \\
11 & 146.34 & 64.71 & 0.305 & 0.496 & 1.032 & 0.183 \\
12 & 102.55 & 46.04 & 0.278 & 0.367 & 0.726 & 0.165 \\
\hline
\end{tabular}


Table 2 (Continued)

\begin{tabular}{ccccccc}
\hline Sample locations & Raeq $\left(\mathrm{Bq} \mathrm{kg}^{-1}\right)$ & Dose rate $\left(\mathrm{nGy} \mathrm{h}^{-1}\right)$ & $\mathrm{Hex}$ & $\mathrm{H}_{\mathrm{in}}$ & $\mathrm{I}_{\mathrm{rr}}$ & $\mathrm{I} \alpha$ \\
\hline 13 & 101.24 & 45.50 & 0.275 & 0.360 & 0.718 & 0.158 \\
14 & 90.25 & 40.67 & 0.245 & 0.323 & 0.641 & 0.145 \\
15 & 133.29 & 59.20 & 0.361 & 0.462 & 0.939 & 0.186 \\
16 & 86.77 & 38.94 & 0.2350 & 0.309 & 0.815 & 0.135 \\
17 & 71.92 & 32.38 & 0.196 & 0.254 & 0.512 & 0.1081 \\
18 & 149.10 & 66.02 & 0.404 & 0.512 & 1.050 & 0.200 \\
19 & 97.89 & 44.14 & 0.266 & 0.365 & 0.691 & 0.182 \\
20 & 137.80 & 60.74 & 0.373 & 0.457 & 0.972 & 0.156 \\
21 & 143.79 & 63.60 & 0.390 & 0.488 & 1.014 & 0.182 \\
\hline Average & 96.24 & 43.27 & 0.256 & 0.346 & 0.691 & 0.157 \\
\hline Worldwide average & $<370$ & 55 & $<1$ & $<1$ & $<1$ & $<1$ \\
\hline
\end{tabular}

\subsubsection{Absorbed Gamma Dose Rate (D)}

The external outdoor absorbed gamma dose rate due to terrestrial gamma rays from the nuclides for ${ }^{226} \mathrm{Ra},{ }^{232} \mathrm{Th}$ and ${ }^{40} \mathrm{~K}$ at $1 \mathrm{~m}$ above the ground level were calculated as follows outlined by: ${ }^{10}$

$$
\mathrm{D}\left(\mathrm{nGy} \mathrm{h}^{-1}\right)=0.462 \mathrm{~A}_{\mathrm{Ra}}+0.604 \mathrm{~A}_{\mathrm{Th}}+0.0417 \mathrm{~A}_{\mathrm{K}}
$$

where $A_{\text {Ra }}, A_{\mathrm{Th}}$ and $A_{\mathrm{K}}$ are the specific activities of ${ }^{226} \mathrm{Ra},{ }^{232} \mathrm{Th}$ and ${ }^{40} \mathrm{~K}$, respectively. The highest value of dose rate was $66.02 \mathrm{nGy} \mathrm{h}^{-1}$ in Sample 18, while the lowest value was $18.67 \mathrm{nGy} \mathrm{h}^{-1}$ in Sample 2 with an average value of $43.27 \mathrm{nGy} \mathrm{h}^{-1}$. The results of $\mathrm{Ra}_{\mathrm{eq}}$ and $\mathrm{D}$ results are shown graphically in Figure 2.

\subsubsection{External hazard indices $\left(H_{e x}\right)$ and internal hazard indices $\left(H_{\mathrm{in}}\right)$}

$\mathrm{H}_{\text {ex }}$ is obtained from $\mathrm{R}_{\text {aeq }}$ expression through the supposition that its maximum value allowed (equal to unity) corresponds to the upper limit of $R_{\text {aeq }} 370 \mathrm{~Bq} \mathrm{~kg}^{-1}$. This index value must be less than unity in order to keep the radiation hazard insignificant, i.e., the radiation exposure due to the radioactivity from construction materials is limited to $1.0 \mathrm{mSv} \mathrm{y}^{-1}$. The $\mathrm{H}_{\mathrm{ex}}$ can be defined as: ${ }^{11}$

$$
H_{e x}=\frac{A_{\mathrm{Ra}}}{370}+\frac{A_{T h}}{370}+\frac{A_{K}}{370} \leq 1
$$

where $A_{\text {Ra }}, A_{\mathrm{Th}}$ and $A_{\mathrm{K}}$ are the specific activities of ${ }^{226} \mathrm{Ra},{ }^{232} \mathrm{Th}$ and ${ }^{40} \mathrm{~K}$, respectively. 


\section{Radium Equivalent Activity and Absorbed Gamma Dose Rate}

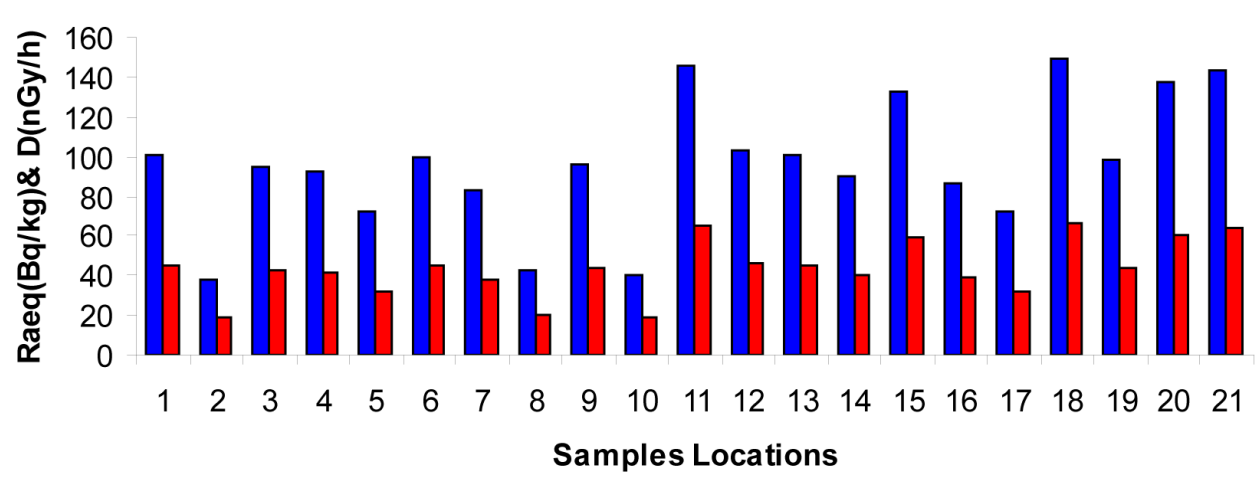

Figure 2: Radium equivalent activity, $\mathrm{Ra}_{\mathrm{eq}}\left(\mathrm{Bq} \mathrm{kg}^{-1}\right)$ and Absorbed gamma dose rate, $\mathrm{D}\left(\mathrm{nGy} \mathrm{h}^{-1}\right)$ results for soil samples.

The internal exposure is caused by the inhalation of radon gas and its relevant examples which can be expressed in terms of $H_{\text {in }}$ and calculated with equation below: ${ }^{12}$

$$
\mathrm{H}_{\mathrm{in}}=\mathrm{A}_{\mathrm{Ra}} / 185+\mathrm{A}_{\mathrm{Th}} / 259+\mathrm{A}_{\mathrm{k}} / 4810 \leq 1
$$

The values of $H_{\text {ex }}$ and $H_{\text {in }}$ were varied from 0.105 in Sample 2 to 0.404 in Sample $18,0.178$ in Sample 2 to 0.512 in Sample 18 respectively, with an average value of 0.256 and 0.346 . It should be added that this factor must be less than unity, so that it is placed within the allowable universal value.

\subsubsection{Gamma index $\left(\mathbf{I}_{\gamma \mathrm{r}}\right)$}

Another radiation hazard called the representative level index or gamma index $\left(\mathrm{I}_{\gamma \mathrm{r}}\right)$, is defined as follows: ${ }^{13}$

$$
\mathrm{I}_{\gamma \mathrm{r}}=\mathrm{A}_{\mathrm{Ra}} / 150+\mathrm{A}_{\mathrm{Th}} / 100+\mathrm{A}_{\mathrm{k}} / 1500 \leq 1
$$

where $A_{\mathrm{Ra}}, A_{\mathrm{Th}}$ and $A_{\mathrm{K}}$ are the specific activities of ${ }^{226} \mathrm{Ra},{ }^{232} \mathrm{Th}$ and ${ }^{40} \mathrm{~K}$ in $\mathrm{Bq} \mathrm{kg}{ }^{-1}$, respectively. $\mathrm{I}_{\gamma \mathrm{r}}$ varied from 0.281 in Sample 2 to 1.050 in Sample 18 with an average value of 0.157 .

\subsubsection{Alpha index (I $\alpha)$}

Also, several indices dealing with assessment of the excess alpha radiation due to the radon inhalation originating from building materials called alpha index (I $\alpha)$ or internal index have been developed. ${ }^{15}$ In the present work, (I $\left.\alpha\right)$ was determined through the following formula: ${ }^{14}$ 


$$
\mathrm{I} \alpha=\mathrm{A}_{\mathrm{Ra}} / 200 \mathrm{~Bq} / \mathrm{kg} \leq 1
$$

The values of $\mathrm{I} \alpha$ ranged from 0.138 in Sample 2 to 0.200 in Sample 18 with an average of 0.157 .

The calculated values of $\mathrm{Ra}_{\mathrm{eq}}, \mathrm{D}, \mathrm{H}_{\mathrm{ex}}, \mathrm{H}_{\mathrm{in}}, \mathrm{I} \gamma$ and $\mathrm{I} \alpha$ are listed in Table 2.

\subsubsection{The annual effective dose}

To calculate the annual effective dose, the following must be taken into consideration: first, the conversion factor of absorbed dose to effective dose; and second, the internal occupation factor. The factor from observed dose in the air is used in the annual effective dose received by adult and 0.8 is put as the internal occupation (which is the ratio of time spent at home) and 0.2 put as external occupation as below: ${ }^{16,17}$

$$
\begin{aligned}
& \mathrm{E}_{\text {in }}\left(\mathrm{mSv} \mathrm{y}^{-1}\right)=\mathrm{D}\left(\mathrm{nGy} \mathrm{h}^{-1}\right) \times 8.760\left(\mathrm{~h} \mathrm{y}^{-1}\right) \times 0.8 \times 0.7 \mathrm{~Sv} \mathrm{G}^{-1} \times 10^{-6} \\
& \mathrm{E}_{\text {out }}\left(\mathrm{mSv} \mathrm{y}^{-1}\right)=\mathrm{D}\left(\mathrm{nGy} \mathrm{h}^{-1}\right) \times 8.760\left(\mathrm{~h} \mathrm{y}^{-1}\right) \times 0.2 \times 0.7 \mathrm{~Sv} \mathrm{G}^{-1} \times 10^{-6}
\end{aligned}
$$

The values of indoor annual effective dose and outdoor annual effective dose varied from $0.0916 \mathrm{mSv} \mathrm{y}^{-1}$ in Sample 2 to $0.323 \mathrm{mSv} \mathrm{y}^{-1}$ in Sample 18, $0.0229 \mathrm{mSv} \mathrm{y}^{-1}$ in Sample 2 to $0.0809 \mathrm{mSv} \mathrm{y}^{-1}$ in Sample 18 with an average value of $0.42 \mathrm{mSv} \mathrm{y}^{-1}$ and $0.08 \mathrm{mSv} \mathrm{y}^{-1}$ respectively.

The annual effective dose rate outdoors in units of $\mathrm{mSv}^{-1}$, is also can be calculated by the following formula: ${ }^{18}$

$$
\text { Annual Effective Dose Rate }\left(\mathrm{mSv} \mathrm{y}^{-1}\right)=\mathrm{D} \times \mathrm{T} \times \mathrm{F}
$$

where $\mathrm{D}$ is the calculated dose rate (in $\mathrm{nGy} \mathrm{h}^{-1}$ ), $\mathrm{T}$ is the outdoor occupancy time $\left(0.2 \times 24 \mathrm{~h} \times 365.25, \mathrm{~d} \approx 1753 \mathrm{~h} \mathrm{y}^{-1}\right)$, and $\mathrm{F}$ is the conversion factor $\left(0.7 \times 10^{-6} \mathrm{~Sv} \mathrm{~Gy}^{-1}\right)$. Table 3 shows the values of the indoor and outdoor effective dose rate and the annual effective dose rate. The indoor annual effective dose and outdoor annual effective dose rate are shown graphically in Figure 3.

The specific activities measured in this study were compared with those from other countries (Table 4 and Table 5). The ${ }^{226} \mathrm{Ra}$ activity concentration for virgin soils in our study was higher than Nigeria but less compared to those values recorded in Yemen, Bangladesh, China, Turkey, Botswana, Malaysia and Iraq, as in Table 4. On the other hand, the value of the agricultural soils in the present study was higher than Pakistan, but less than those in Yugoslavia, Egypt, Algeria, Iraq and Malaysia, as in Table 5. The specific activity of ${ }^{232} \mathrm{Th}$ for virgin soils in the study area was 
less than other countries except Nigeria and Iraq, while its value in agricultural soils was less than all the countries except Iraq. The ${ }^{40} \mathrm{~K}$ specific activity values for both virgin and agricultural soils in this study were less than those in all other the countries.

\section{Indoor and Outdoor Effective Dose Rate}

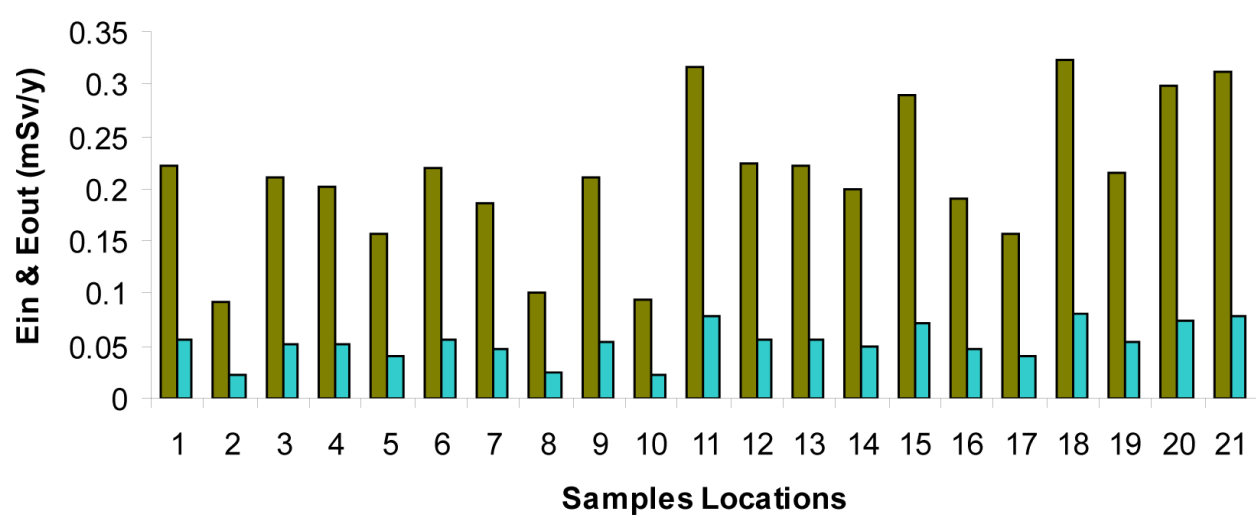

Figure 3: Annual effective dose $\mathrm{E}_{\mathrm{in}}$ and annual effective dose $\mathrm{E}_{\text {out }}$ results.

Table 3: The indoor and outdoor effective dose rate and the annual effective dose rate of soil samples.

\begin{tabular}{cccc}
\hline Sample locations & $\mathrm{E}_{\text {in }}\left(\mathrm{mSv} \mathrm{y}^{-1}\right)$ & $\mathrm{E}_{\text {out }}\left(\mathrm{mSv} \mathrm{y}^{-1}\right)$ & Annual effective dose rate $\left(\mathrm{mSv} \mathrm{y}^{-1}\right)$ \\
\hline 1 & 0.222 & 0.0556 & 0.0556 \\
2 & 0.0916 & 0.0229 & 0.0229 \\
3 & 0.210 & 0.0525 & 0.0525 \\
4 & 0.203 & 0.0508 & 0.0508 \\
5 & 0.158 & 0.0395 & 0.0395 \\
6 & 0.220 & 0.0550 & 0.0550 \\
7 & 0.186 & 0.0466 & 0.0467 \\
8 & 0.101 & 0.0253 & 0.0254 \\
9 & 0.212 & 0.0532 & 0.0532 \\
10 & 0.0943 & 0.0235 & 0.0236 \\
11 & 0.317 & 0.0793 & 0.0794 \\
12 & 0.225 & 0.0564 & 0.0565 \\
13 & 0.223 & 0.0558 & 0.0558 \\
14 & 0.199 & 0.0498 & 0.0499 \\
15 & 0.290 & 0.0726 & 0.0726 \\
16 & 0.191 & 0.0477 & 0.0477 \\
\hline
\end{tabular}


Table 3 (Continued)

\begin{tabular}{cccc}
\hline Sample locations & $\mathrm{E}_{\text {in }}\left(\mathrm{mSv} \mathrm{y}^{-1}\right)$ & $\mathrm{E}_{\text {out }}\left(\mathrm{mSv} \mathrm{y}^{-1}\right)$ & Annual effective dose rate $\left(\mathrm{mSv} \mathrm{y}^{-1}\right)$ \\
\hline 17 & 0.158 & 0.0397 & 0.0397 \\
18 & 0.323 & 0.0809 & 0.0810 \\
19 & 0.216 & 0.0541 & 0.0541 \\
20 & 0.298 & 0.0745 & 0.0745 \\
21 & 0.312 & 0.0790 & 0.0780 \\
\hline Average & 0.212 & 0.0572 & 0.0530 \\
\hline Worldwide average & 0.42 & 0.08 & 0.08 \\
\hline
\end{tabular}

Table 4: Comparison of radioactivity levels in virgin soil samples with other countries.

\begin{tabular}{lcccc}
\hline \multicolumn{5}{c}{ Virgin soil } \\
\hline \multicolumn{1}{c}{ Country } & ${ }^{226}{\mathrm{Ra}\left(\mathrm{Bq} \mathrm{kg}^{-1}\right)}^{232} \mathrm{Th}^{\left(\mathrm{Bq} \mathrm{kg}^{-1}\right)}$ & ${ }^{40} \mathrm{~K}\left(\mathrm{~Bq} \mathrm{~kg}^{-1}\right)$ & Reference \\
\hline Yemen & 44 & 58 & 822 & {$[19]$} \\
Bangladesh & 60.20 & 60.80 & 928.00 & {$[20]$} \\
Nigeria & 18 & 22 & 210 & {$[21]$} \\
China & 38 & 57.6 & 838 & {$[22]$} \\
Turkey & 115 & 192 & 1207 & {$[23]$} \\
Botswana & 34.8 & 41.8 & 432.7 & {$[24]$} \\
Malaysia (Penang) & 396 & 165 & 835 & {$[25]$} \\
Malaysia (Pontian) & 37 & 53 & 293 & {$[26]$} \\
Malaysia & 51.6 & 78.44 & 125.66 & {$[27]$} \\
Iraq & 32.52 & 20.30 & 378.93 & {$[28]$} \\
Egypt & 31.44 & 39.77 & 113.23 & Present study \\
\hline
\end{tabular}

Table 5: Comparison of radioactivity levels in agriculture soil samples with other countries.

\begin{tabular}{lcccc}
\hline \multicolumn{1}{c}{ Country } & ${ }^{226} \mathrm{Ra}\left(\mathrm{Bq} \mathrm{kg}^{-1}\right)$ & $\left.{ }^{232} \mathrm{Th}_{(\mathrm{Bq} \mathrm{kg}}{ }^{-1}\right)$ & ${ }^{40} \mathrm{~K}\left(\mathrm{~Bq} \mathrm{~kg}^{-1}\right)$ & Reference \\
\hline Yugoslavia & 39.3 & 53 & 454 & {$[29]$} \\
Pakistan & - & $50.6-64$ & $560.2-625.6$ & {$[30]$} \\
Pakistan & 30 & 56 & 602 & {$[31]$} \\
Egypt & 43 & 54 & 183 & {$[32]$} \\
Algeria & 53.2 & 50.03 & 311 & {$[33]$} \\
Malaysia & 80.63 & 116.87 & 200.66 & {$[27]$} \\
Iraq & 33.55 & 21.52 & 326.74 & {$[34]$} \\
Egypt & 31.44 & 39.77 & 113.23 & Present study \\
\hline
\end{tabular}




\section{CONCLUSION}

It is important to determine the background radiation level in order to evaluate the health hazards. The average specific activity values for ${ }^{226} \mathrm{Ra}$ and ${ }^{40} \mathrm{~K}$ are below the worldwide average, except for ${ }^{232} \mathrm{Th} .{ }^{16}$ Additionally, the average value of the eight radiation hazard indices was found to be less than the average recommended indices given by the worldwide average. ${ }^{16}$ The data produced in the present work can be used as baseline radiological data for future investigations.

\section{REFERENCES}

1. White, R. E. (2013). Principles and practice of soil science: The soil as natural resource. New York: John Wiley \& Sons.

2. Gbadebo, A. M. \& Amos, A. J. (2010). Assessment of radionuclide pollutants in bedrocks and soils from Ewekoro cement factory, southwest Nigeria. Asia. J. Appl. Sci., 3(2), 135-144.

3. Kurnaz, A. et al. (2007). Determination of radioactivity levels and hazards of soil and sediment samples in Firtina Valley (Rize, Turkey). App. Radiat. Isot., 65(11), 1281-1289.

4. El-Taher, A. et al. (2016). Ecological impacts of Al-Jalamid phosphate mining, Saudi Arabia: Soil elemental characterization and spatial distribution with INAA. App. Radiat. Isot., 107, 382-390.

5. El-Taher, A. (2012). Assessment of natural radioactivity levels and radiation hazards for building materials used in Qassim area, Saudi Arabia, Roman. J. Phys., 57, 726-735.

6. El-Taher, A. (2011). Terrestrial gamma radioactivity levels and their corresponding extent exposure of environmental samples from Wadi El Assuity protective area, Assuit, Upper Egypt. Radiat. Prot. Dosim., 145(4), 405-410.

7. IAEA. (1979). Gamma-ray surveys in uranium exploration. Technical Report Series No. 186.Vienna, IAEA.

8. Vosniakos, F., Zavalaris, K. \& Papaligas, T. (2003). Indoor concentration of natural radioactivity and the impact to human. J. Environ. Prot. Ecol., 4(3), 733-737.

9. Beretka, J. \& Mathew, P. J. (1985). Natural radioactivity of Australian building materials, industrial wastes and by-products. Health Phys., 48, 87-95.

10. Kessaratikoon, P. \& Awaekechi, S. (2008). Natural radioactivity measurement in soil samples collected from municipal area of Hat Yai District in Songkhla Province, King Mongkut's Institute of Technology Ladkrabang. Sci. J., 8(2), 52-58. 
11. Xinwei, L. (2005). Natural radioactivity in some building materials of Xi' an China Radiat. Meas., 40, 94-97.

12. Uosif, M. A. M. \& El-Taher, A. (2008). Radiological assessment of AboTatur Phosphate, Western Desert, Egypt. J. Radiat. Prot. Dosim., 130(2), 228-235.

13. Kafala, S. I. \& Macmahon, T. D. (2007). Comparison of neutron activation analysis methods. Radiat. Phys. Chem., 71, 507-516.

14. Abbady, A. G., Uosif, M. A. \& El-Taher, A. (2005). Natural radioactivity and dose rate assessment of phosphate rocks from Wadi El-Mashash and ElMahamid mines, Egypt. J. Environ. Radioact., 84(1), 65-78.

15. El-Gamal, A., Nasr, S. \& El-Taher, A. (2007). Study of the spatial distribution of natural radioactivity in the Upper Egypt nile river sediments. Radiat. Meas., 42, 457-465.

16. United Nations Scientific Committee on the Effect of atomic Radiation, UNSCEAR. (2008). Effects of the atomic radiation. Report to the General Assembly with Scientific Annexes, United Nations, New York.

17. El-Taher, A. \& Madkour, H. A. (2014). Environmental and radio-ecological studies on shallow marine sediments from harbour areas along the Red Sea coast of Egypt for identification of anthropogenic impacts. J. Isot. Environ. Health Stud., 50, 120-133, http://dx.doi.org/10.1080/10256016.2013.8262 11.

18. El-Taher, A. \& Uosif, M. A. M. (2006). The assessment of the radiation hazard indices due to uranium and thorium in some Egyptian environmental matrices. J. Phys. D Appl. Phys., 39, 4516-4521.

19. Abd. El-Mageed, A. et al. (2011). Assessment of natural and anthropogenic radioactivity levels in rocks and soils in the environments of Juban town in Yemen. Radiat. Phys. Chem., 80, 710-715.

20. Alam, M. N. et al. (1999). Radiation dose estimation from the radioactivity analysis of lime and cement used in Bangladesh. J. Environ. Radioact., 42, $77-85$.

21. Agbalagba, E. \& Onoja, R. (2011). Evaluation of natural radioactivity in soil, sediment and water samples of Niger Delta (Biseni) flood plain lakes. Nigeria. J. Environ. Radioact., 102, 667-671.

22. Ziqiang, P., Yin, Y. \& Mingqiang, G. (1988). Natural radiation and radioactivity in China. Radiat. Prot. Dosim., 24, 29-38.

23. Merdanoğlu, B. \& Altınsoy, N. (2006). Radioactivity concentrations and dose assessment for soil samples from Kestanbol granite area, Turkey. Radiat. Prot. Dosim., 121, 399-405.

24. Murty, V. \& Karunakara, N. (2008). Natural radioactivity in the soil samples of Botswana. Radiat. Meas., 43, 1541-1545. 
25. Ahmad, N. et al. (2015). An overview on measurements of natural radioactivity in Malaysia. J. Radiat Res. Appl. Sci., 8(1), 136-141.

26. Saleh, M. A. et al. (2013). Assessment of natural radiation levels and associated dose rates from surface soils in Pontian district, Johor, Malaysia. J. Ovonic. Res., 9, 17-27.

27. Nisar, A., Suhaimi Jaafar, M. \& Alsaffar, M. S. (2015). Natural radioactivity in virgin and agricultural soil and its environmental implications in Sungai Petani, Kedah, Malaysia. Pollut., 1(3), 305-313.

28. Najam, L. A., Younis Shaher, A. \& Kithah Fouzey, H. (2015). Natural radioactivity in soil samples in nineveh province and the associated radiation hazards. Int. J. Phys., 3(3), 126-132.

29. Bikit, I. et al. (2004). Radioactivity of the soil in Vojvodina (northern province of Serbia and Montenegro). J. Environ. Radioact., 78, 11-19.

30. Akhtar, N., Tufail, M. \& Ashraf, M. (2005). Natural environmental radioactivity and estimation of radiation exposure from saline soils. Int. J. Environ. Sci. Tech., 1, 279-285.

31. Tufail, M., Akhtar, N. \& Waqas, M. (2006). Measurement of terrestrial radiation for assessment of gamma dose from cultivated and barren saline soils of Faisalabad in Pakistan. Radiat. Meas., 41, 443-451.

32. Issa, S. A. (2013). Radiometric assessment of natural radioactivity levels of agricultural soil samples collected in Dakahlia, Egypt. Radiat. Prot. Dosim., 56(1), 59-67.

33. Boukhenfouf, W. \& Boucenna, A. (2011). The radioactivity measurements in soils and fertilizers using gamma spectrometry technique. J. Environ. Radioact., 102, 336-339.

34. Najam, L. A. \& Younis, S. A. (2015). Assessment of natural radioactivity level in soil samples for selected regions in Nineveh Province (Iraq). Int. J. Novel Res. Phys. Chem. Math., 2(2), 1-9. 